\title{
LA VIRGEN DE LOS REYES Y LAS SOMBRAS ERRANTES DE SU LEYENDA
}

\author{
POR \\ MARÍA DE LOS ÁNGELES GUTIÉRREZ ROMERO ${ }^{1}$ \\ Universidad de Cádiz
}

\section{RESUMEN}

El presente artículo tiene como objeto establecer los paralelismos existentes entre la iconografía y los recursos orales vinculados a la tradición de las leyendas marianas a ambos lados del Atlántico. A partir de la reproducción de una variante inédita de la leyenda de la sevillana Virgen de los Reyes, auspiciadora de las conquistas de Fernando III el Santo, se dará cuenta de una rica tradición reflejada en autos sacramentales durante los Siglos de Oro y de relatos populares que conjugarán los hechos históricos con lo maravilloso y sobrenatural.

PALABRAS CLAVE: Virgen de los Reyes; Fernando III de Castilla; leyendas cristianas; Virgen María-Iconografía; tradición oral.

\section{THE “VIRGEN DE LOS REYES” AND THE WANDERING SHADOWS OF HER LEGEND}

\author{
ABSTRACT \\ This paper aims to establish the parallels between the iconography and oral resources linked to the tradition of the Virgin \\ Mary's legends on both sides of the Atlantic. Starting from the reproduction of an unpublished variant of the legend of the "Virgen \\ de los Reyes" (Our Lady of Monarchs), sponsor of the conquests of Ferdinand the Third, it will lead to a rich tradition reflected \\ in "autos sacramentales" during the 16th and 17th centuries and in popular stories that will combine historical facts with the \\ marvelous and supernatural.
}

KEY WORDS: "Virgen de los Reyes"; Ferdinand the Third of Castile; Christian legends; Virgin Mary-Iconography; oral tradition.

Cómo CITAR ESTE ARTículo / CitATION: Gutiérrez Romero, M.a Á. 2019. "La Virgen de los Reyes y las sombras errantes de su leyenda». Hispania Sacra 71, 143: 77-87. https://doi.org/10.3989/hs.2019.005

$\begin{array}{ll}\text { Recibido/Received } & 27-09-2017 \\ \text { Aceptado/Accepted } & 22-01-2018\end{array}$

\section{CUANDO LA MADERA INERTE COBRA VIDA. ORÍGENES DE LA LEYENDA}

La explicación a ciertos hechos sobrenaturales ${ }^{2}$ a lo largo de la historia muchas veces ha sido canalizada por medio de una acción divina. Ya apuntaba Santo Tomás que «lo sobrenatural, en sí mismo es invisible [pero] asume medios visibles para manifestarse y obrar entre los hombres». ${ }^{3}$ Así pues, se encontraba una justificación a la larga tradición

1 mariangeles.gutierrezromero@alum.uca.es / ORCID iD: https:// orcid.org/0000-0001-7220-1846

2 Como recoge Freedberg (1992: 105-106), la concepción de "lo sobrenatural" tiene un significado preciso dentro de un determinado grupo social o sistema de pensamiento. No obstante, en nuestro análisis, cuando hablamos de determinados objetos (en este caso, de una escultura) sí es pertinente ya que tiene ciertas capacidades como la movilidad o la funcionalidad que no muestran otros casos por propia iniciativa.

3 Ramos. A. 2008: 76. de imágenes religiosas de las que se decía que llegaban a cobrar vida y cuyas milagrosas intervenciones dieron lugar a interminables afluentes de leyendas.

Tal es el caso de la escultura que ostenta el título de Virgen de los Reyes que preside la Capilla Real de la Catedral de Sevilla. Su culto ha estado dignificado por su estatus como Madre de Dios y protectora de Reyes pero, al mismo tiempo, el fervor popular ha hecho correr historias que, más allá de inspirar un sentimiento piadoso, ha servido para envolverla dentro de un enigmático misterio.

Esa es la razón por la que este trabajo parte del conocimiento de una de esas leyendas en la que se imbrican las pruebas fehacientes del poder divino con las primitivas raíces de las manifestaciones artísticas religiosas para explicar la trascendencia de un crucial trasfondo histórico.

La especialista en historia oral, Miren Llona, recala en la importancia del estudio de este tipo de fuentes dentro 
de la historiografía, en cuanto a que permiten «descubrir la forma en que los seres humanos han dado sentido al mundo [...] dentro de universos culturales determinados». ${ }^{4}$ De esta manera, las capas de significado que encierra una leyenda de esta clase nos va a remitir no solo a su vertiente antropológica, sino también filosófica y teológica. Para el alemán Hans Belting, la Edad Media fue principalmente la era de las imágenes, las cuales «no han sido nunca asunto exclusivo de la religión, sino también de la sociedad, que se representaba en y con la religión». ${ }^{5}$

Siguiendo la tradición cristiana, la tumba de María fue encontrada vacía, lo que se interpretó como una demostración de su ascensión a los cielos. De ahí que se asegurara «su veneración universal al no estar concentrada su "presencia" en pocos y exclusivos lugares de la geografía de la santidad cristiana» y que se incidiera en el alcance milagroso que podían llegar a tener sus reliquias o sus imágenes. ${ }^{6}$

La devoción que la Virgen de los Reyes ha suscitado a través de los siglos, se remonta a la época medieval en la que se reafirmó su poder divino como intercesora de la victoria de los cristianos sobre la Sevilla musulmana, y más tarde como figura privilegiada y legitimadora de las sucesivas casas dinásticas. Por ello su trascendencia a través del tiempo ha quedado arraigada no solo en la suntuosidad de su capilla, sino en la memoria y en el eco de las leyendas, contadas de generación en generación por todos aquellos sevillanos y creyentes que, por costumbre, tienen un azulejo o una pequeña réplica pequeña de barro, la cual, desde detrás de los cristales de una alacena, les protege la casa.

La leyenda principal ${ }^{7}$ que envuelve a esta imagen de amable sonrisa y dedos recubiertos de frágil encarnadura tiene lugar cuando el santo rey Fernando III se hallaba sitiando la ciudad de Sevilla en 1248.

Recogen las fuentes populares a las que hacen referencia estos autores, que una pertinaz sequía amenazaba al ganado y la cosecha. Como consecuencia, el rey volvió a dar muestras de su exaltada fe y decidió imponerse sacrificios de ayuno y cilicios implorando la intercesión de la Virgen para remediar el mal. Abandonó pues el campamento y se retiró en soledad durante tres días para hacer penitencia y fue así como se le apareció la Virgen con su Hijo en los brazos, prometiéndole terminar con la sequía en algunas versiones, y en otras, asegurándole la conquista de Isbiliya. Tras esa aparición, el rey quiso que se ejecutase una escultura en la que se reflejase con la mayor fidelidad los rasgos de la Virgen aparecida. Por ello, convocó a notables escultores que intentaron labrar la imagen varias veces, sin conseguir ninguna de ellas agradar al monarca. ${ }^{8}$ Mas un buen día,

\footnotetext{
4 Llona, M. 2012: 42.

5 Belting, H. 2009: 11.

6 Navarro, A.M. 2013: 332-333.

7 Hernández Díaz 1996: 19; Carrero Rodríguez 1989: 28-30.

8 Todas aquellas imágenes que el rey iba rechazando conforman el llamado "círculo de imágenes fernandinas», las cuales poseen características morfológicas muy similares. Se trata de la Virgen de las Aguas (título que podría corresponder con el milagroso remedio de la sequía o en alusión a una frase del monarca de que se quedaba entre dos aguas, respecto al parecido de esta figura con el original aparecido) y que se encuentra en la Iglesia del Salvador, junto con otras dos figuras que comparten la advocación de Virgen de los Reyes, veneradas en los templos sevillanos de San Clemente y San Idelfonso (Hernández Díaz 1996: 24-31).
}

cuando ya se comenzaba a perder la esperanza, aparecieron por el campamento dos (o tres) peregrinos que procedían de Alemania, dando a entender que eran maestros escultores, y se ofrecieron para llevar a cabo la talla de la Virgen María con la condición de trabajar en total aislamiento. El rey les proporcionó todo el material y las herramientas necesarias y se retiraron a una torre; ${ }^{9}$ un lugar apartado para trabajar sin ser vistos y sin que nadie los incomodara. Pasados unos días sin noticia de ellos, al acudir al lugar, se encontraron con que no había nadie excepto una bella imagen de María a la que rápidamente Fernando III identificó como la que había visto en sueños. Aquello fue considerado como un milagro y por ello se supo que los artífices de la imagen habían sido ángeles enviados por el Cielo.

La Primera Crónica General cuenta cómo, tras quince meses de asedio, se produce la clamorosa entrada del rey y su corte a la ciudad el 22 de diciembre de 1248 y «fue reçebido con muy grant proçesion de obispos et de toda la clerizia et de todas las otras gentes, con muy grandes alegrías et con muy grandes bozes, loando et bendiziendo [...] et entro asi desta gisa ese bienauenturado rey don Fernando en la yglesia de Santa María ", ${ }^{10}$ cerrando la comitiva la imagen de la Virgen de los Reyes en un carro triunfal.

Desde entonces, la devoción a esta virgen gótica (Fig. 1) quedará estrechamente ligada a la personalidad de Fernando III, quien encarnó el paradigma de ser un soberano justo, un héroe invencible y un cristiano ejemplar, merecedor de gozar del favor divino que lo ayudaba en sus conquistas bélicas. Fue el mismo rey quien quiso ser enterrado a los pies de la imagen para que lo velase en su eterno descanso, en el altar mayor de la catedral mudéjar de Sevilla. No en vano, ese vínculo quedará también inmortalizado en las Cantigas de Santa María donde su sucesor, Alfonso X, en la cantiga 295, habla de la aparición de Santa María a un rey que a sus figuras «mandava sempre fazer, muit apóstas e fremosas; e fazía-as vestir» adornándolas con ricos paños de oro y piedras preciosas, tal y como la Virgen de los Reyes era engalanada. ${ }^{11}$

Al fallecer en 1252, no tardó el propio rey en empezar a ser venerado con estatus de santo, siendo celebrado cada año el aniversario de su muerte en el que la ciudad de Sevilla se paralizaba y se realizaban ofrendas en torno a su sepulcro. Así pues, durante el siglo XVII, con el auspicio de la Contrarreforma, se puso de manifiesto en un memorial el interés por la «inclusión de un monarca español en el catálogo de los santos [que] vendría a aumentar la grandeza del reino y la de su monarca», siendo las consecuencias para la ciudad de Sevilla «el aumento de su ya elevado prestigio

9 Se ha querido identificar con la torre de los Herberos, en el término de Dos Hermanas. Este elemento a su vez no es casual: la torre tiene una simbología ascensional; una escala que une cielo y tierra en el que la altura material equivale a la elevación espiritual. También es un símbolo mariano, como recuerdan las letanías y se recogen en numerosas pinturas y grabados.

10 Menéndez Pidal 1906: 767.

11 Existe además otras cantigas, como la 221, en las que se cuenta cómo el rey Fernando, siendo niño, cayó gravemente enfermo y que, gracias a las plegarias ofrecidas por su madre, doña Berenguela, fue milagrosamente curado por la intercesión de la Virgen. Caso similar fue el de la reina Beatriz en la cantiga 256, que a causa de una enfermedad con gran peligro de su vida, fue salvada al besar una imagen mariana. 
FIGURA 1

Imagen de la Virgen de los Reyes. Fotografía de Rafael Rodríguez Hernández

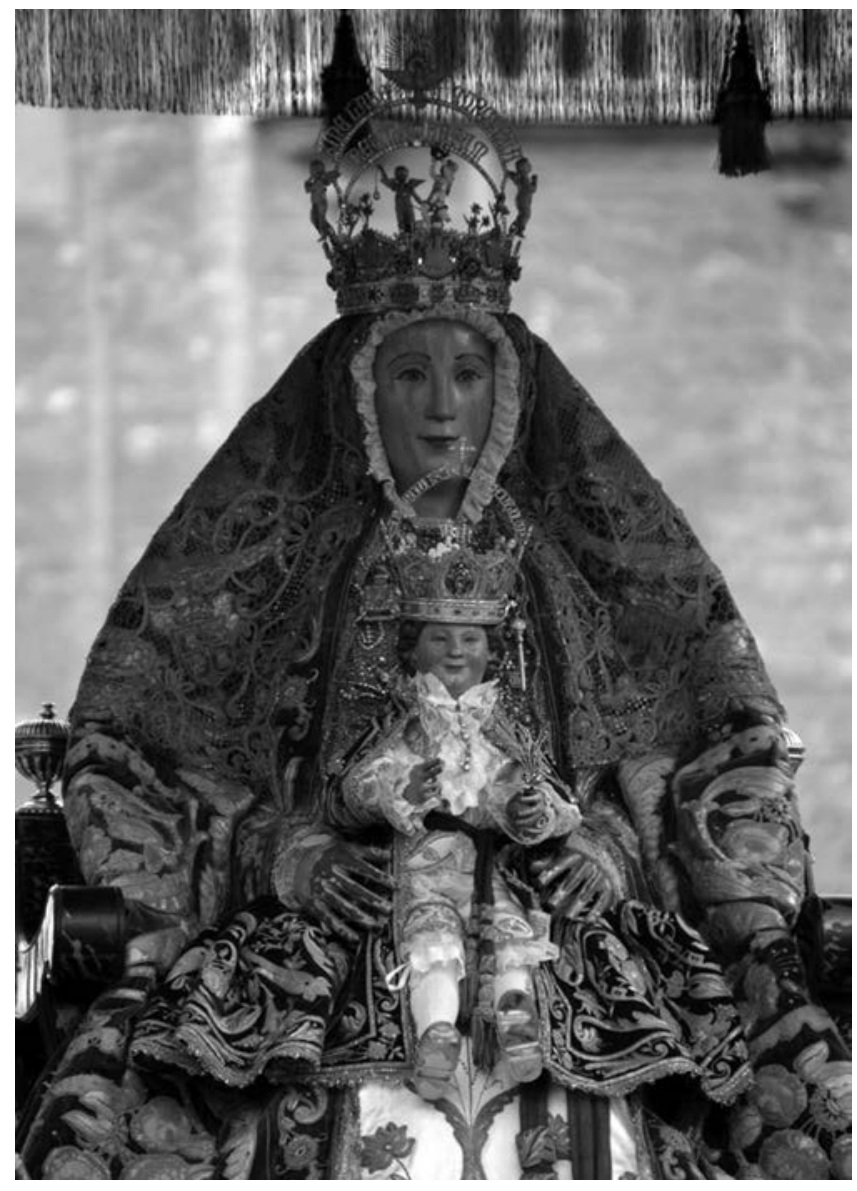

religioso, al conservar las principales reliquias del santo, e indirectamente beneficios económicos $»{ }^{12}$ La cantidad de hagiografías y milagros atribuidos por los fieles impulsó en los años cincuenta su proceso de canonización y se produjo una explosión iconográfica de esculturas e imágenes como el famoso cuadro pintado por Murillo que fue profusamente reproducido- los cuales tomaron como principal referencia un grabado ${ }^{13}$ de 1630 en el que se adoptaba el modelo barroco de retrato áulico, donde se conjugaba el simbolismo de su faceta regia como gobernante con atributos como la espada, la corona y el pomo, con atributos divinos como la aureola de santo. ${ }^{14}$ Finalmente, el 7 de febrero de 1671, fue canonizado por el Papa Clemente X, siendo recibida la noticia en Sevilla con magnas fiestas.

Tal popularidad no quedó ajena a la evocación literaria y buena muestra de ello son la holgada nómina de autores que escribieron sobre la vida del Santo $\operatorname{Rey}^{15}$ y los autos

12 Rodríguez Moya 2007: 151.

13 Este en concreto fue realizado en Roma por Claude Audrán como dedicatoria de Felipe IV.

14 Ibídem: 152

15 Nombraremos como más representativos a Fernando Torre Farfán y su Fiesta de la S. Iglesia Metropolitana y Patriarcal de Sevilla, al nuevo culto del Señor Rey Fernando el Tercero de Castilla y León (1671), Pablo Espinosa de los Monteros con Epítome de la vida y excelentes virtudes del esclarecido y santo rey don Fernando III (1631) y Juan Antonio Vera y Figueroa con San Fernando o Sevilla restaurada (poema heroico dedicado a Felipe IV), 1632, Arellano 2000: 240-241. sacramentales o comedias que fueron representados a la tenue luz de las candilejas. Hasta nosotros ha llegado un ejemplar (conservado en la biblioteca de la Hispanic Society de Nueva York) de la comedia La Virgen de los Reyes, durante mucho tiempo atribuida a Tirso de Molina y que gracias a estudios posteriores se ha demostrado que su verdadero creador fue Hipólito de Vergara - admirado por coetáneos como Lope o Cervantes ${ }^{16}$ y a quien se ha querido vincular a la escuela poética sevillana-, siendo la obra publicada en 1629. Vergara incorpora la antes expuesta tradición popular del prodigioso origen de la imagen de la Virgen de los Reyes, y puebla su obra dramática de personajes históricos decisivos en las campañas de reconquista del rey san Fernando. ${ }^{17}$ Se puede saber, gracias al testimonio autobiográfico de Vergara, en el discurso VII de la propia comedia, que, para conmemorar el Corpus Christi de 1622, se le había encargado a Lope de Vega la redacción de cuatro autos sacramentales, uno de ellos dedicado a la devoción de la Virgen Santísima de los Reyes. Sin embargo, el cabildo sevillano rechazó la obra puesto que no se ajustaba a la tradición popular sobre la autoría angélica de la talla, sino que recurrió a contar el histórico origen francés de la imagen, regalo de san Luis de Francia al santo rey español. Por ello mismo, el auto no llegó a ser representado, ni se tiene constancia de que haya llegado hasta nosotros ningún testimonio documental; sin embargo, propició la escritura de la obra de Vergara, quien se ofreció en caso de que Lope no pudiese cumplir el plazo de entrega. ${ }^{18}$

Otro autor de gran calado como Pedro Calderón de la Barca, con motivo de la celebración de la canonización, contribuyó con autos como El santo rey san Fernando, estrenado en Madrid durante el Corpus de 1671. En él vuelve a recrear la vieja leyenda de la elaboración icónica por parte de los misteriosos peregrinos, ahondando en la idea de que la sobrecogedora belleza de la talla y la fidelidad de sus rasgos - captando lo inconcebible - no podían ser reproducidos por la mano de un artista, sino por una voluntad superior que la realza en su poder de mediadora y benefactora de los hombres. ${ }^{19}$ "La idea de fondo es apuntar que fue el artista máximo (Dios) el verdadero artífice [del icono], de modo que los fieles habrán de contemplarlo con los ojos del alma además de con los del cuerpo». ${ }^{20}$

\section{«DIOS ABRIRÁ. REY ENTRARÁ»}

Por tanto, no es de extrañar que, al calor de las vindicaciones de santidad del rey y de su vínculo con la imagen de la Virgen de los Reyes, la feligresía incentivara leyendas donde la ficción poética y lo histórico se mezclan con lo maravilloso y sobrenatural. Estos relatos orales poseen un intrínseco carácter polimorfo fruto del paso del tiempo, el cual actúa, por un lado, como un lago de ecos olvidados por la fractura

16 Zugasti 2001: 426-427.

7 Para más información sobre el esclarecimiento de la autoría y de la interpretación de la obra, véase el estudio crítico y la edición anotada de Iscla Rovira, Luis. 1975. Hipólito de Vergara. Autor de "La Reina de los Reyes" de Tirso de Molina. Madrid: Consejo Superior de Investigaciones Científicas, Instituto Enrique Florez.

18 Zugasti 2001: 428-429.

19 Feedberg 1992 citado por Zugasti 2006: 249.

20 Zugasti 2006: 651. 
de la memoria (por lo que, de no dejar constancia escrita, difícilmente se volverán a rescatar las versiones más primitivas); pero a su vez, como la otra cara de una misma moneda, cada leyenda se va adaptando a su contexto histórico y se va enriqueciendo con las nuevas innovaciones con las que el sentir popular hace suyos los vestigios de la tradición.

Así es cómo ha llegado hasta mi conocimiento una leyenda que comparte protagonistas con la que hasta ahora nos ha ocupado. Se trata de una variante muy original puesto que difícilmente he encontrado algún informante que la conozca o que haya oído sobre ella y tampoco - entre toda la bibliografía consultada - se encuentra recogida en ningún formato por escrito. La reproduzco a continuación, tal y como me la han transmitido ${ }^{21}$ :

En tiempo de los moros, estando Sevilla con todas las puertas de la muralla cerradas y custodiadas por la guardia mora, el santo rey Fernando se hallaba acampado con todas sus huestes al otro lado del río, en Triana, sitiando la ciudad.

Aun siendo de noche, el rey cristiano rezaba para que se le hiciese la luz y le diese la idea de cómo entrar en Sevilla. Y así, quedose dormido.

Esa misma noche se le apareció la Virgen en sueños, prometiendo ayudarle en la conquista. A la mañana siguiente, cuando el rey despertó, quedó admirado al encontrar a su lado la llave de Sevilla. Aguardó un tiempo prudente hasta el amanecer cuando, con los soldados cristianos, abrió las puertas de la ciudad y los moros quedaron rendidos. El rey moro, encolerizado, preguntó a su guardia cómo era posible que hubiesen entrado. Nadie vio nada, excepto un sarraceno que le advirtió haber visto tan solo a una mujer envuelta en un manto negro. Ella se llegó hasta donde él se encontraba y ya no recordaba más, porque quedó dormido. Fue así como le quitó las llaves de la puerta y se las dio al rey san Fernando.

Al día siguiente, cuando se abrieron las rejas para la liturgia de la mañana, los fieles devotos se dieron cuenta de que unas huellas daban la vuelta a la catedral y conducían hasta la capilla de la Virgen de los Reyes. Entonces contemplaron maravillados que los zapatitos de la Virgen estaban llenos de polvo, como si hubiesen andado. Y fue así como supieron que había sido un milagro de la Virgen.

Sin duda, es una versión aderezada de detalles que son recolectados de otros relatos. Muchos de esos recursos ya estaban presentes en la tradición clásica y fue durante la Edad Media cuando cobraron una dimensión teológica de gran envergadura en torno a la cuestión de la iconoclastia.

Para empezar, se recurre de nuevo al tema de la visión en sueños. María le revela al rey su destino dejándole las llaves de la ciudad como ya hiciera Venus con Eneas al entregarle su armadura. Pero no es el único objetivo de la visita celestial; desde ese momento, el rey va a rechazar a toda figura que no reproduzca con fidelidad los rasgos de la Virgen. Que la imagen onírica sea la que después coincida con la fisonomía de la escultura es una «demostración de autenticidad que radica en la correspondencia entre el rostro soñado y

21 Nombre de la informante: Aurora Romero. Edad: 53 años. Procedencia: Cádiz. Recopilador/a: María de los Ángeles Gutiérrez Romero. Fecha de documentación: 20 de marzo de 2016. Datos adicionales: La familia de la informante es de procedencia sevillana, en concreto esta leyenda fue transmitida por parte de su abuela materna, Joaquina Lorenzo. la imagen» o, en otras palabras, «la vivificación de la réplica [con el] convencimiento de que la imagen poseía las mismas fuerzas que el original». ${ }^{22}$ El hecho de que la escultura no estuviese confeccionada por la mano humana (archeiropoietica) sino por la de los ángeles, «responde tanto al tabú de la imagen del cristianismo primitivo como a las críticas posteriores, que afirmaban que los cristianos adoraban obras humanas" y según el propio San Pablo, no pueden ser dioses si han sido elaboradas por la mano del hombre..$^{23}$

En la Antigüedad se pensaba que los dioses podían habitar sus estatuas y por ende, se trataba a estas como si fueran los propios dioses. Pero esa posibilidad de que el espíritu de Dios (o de María) pudiese hacer acto de presencia a través de su estatua se "convirtió en motivo de disputa con los cristianos, que consideraban que una obra hecha de mano humana no podía contener vestigios de la divinidad». ${ }^{24}$

En las querellas iconoclastas de los siglos VIII y IX se expuso la problemática entre la diferencia entre la imagen (el objeto) y lo representado (el prototipo), pero será con el apogeo de imágenes, especialmente durante los siglos XII y XIII, cuando las figuras de la Virgen empiecen a considerarse como expresión visual de la Encarnación; fórmula legitimada por los grandes teólogos de la época como Santo Tomás, por la cual una imagen no debe ser adorada en cuanto a su materia, sino en cuanto a que se transfiere el honor de la adoración de su modelo. Se validará entonces la idea de que las estatuas podían estar infundidas de un poder, energeia o dynamis, (virtus sancta en latín) que procedía del prototipo sagrado y no de la materia inerte. La relación legitimadora que se establece entre el prototipo y su imagen, como ya había sucedido en Bizancio, se articulará en función de su parecido con el original. ${ }^{25}$ Por tanto, dichas imágenes eran proclives a dar señales de vida (en el caso que nos ocupa, con los zapatos manchados tras escapar de la capilla), como ratificación de contener la virtus sancta de la divinidad. ${ }^{26}$

Precisamente de esta leyenda, a diferencia de otros relatos, lo que llama poderosamente la atención es la particularidad - que no la exclusividad-del papel activo que tiene la Virgen María en cuanto a que no solo se limita a aparecer, en sueños o no, como por norma general la divinidad tiende a presentarse ante los mortales; sino que es capaz de deambular entre nosotros en el momento en que su imagen de madera cobra vida, provocando el miedo - e incluso el terror - de quien oye la leyenda ante la mera idea de tal manifestación sobrenatural. Desde luego no sería la primera vez que una deidad camina entre los seres humanos, como ya contaba el poeta romano Ovidio (43 a. C. - 17 d. C.) en su Metamorfosis cuando Ceres, para esconder su identidad, se disfrazó de anciana mientras surcaba el mundo en busca de su hija raptada; o cuando Atenea, la de glaucos ojos, se adentra en los sueños de Telémaco para avisarle de que debía de regresar a Ítaca.

22 Belting 2009: 13, 56.

23 Ibídem: 80.

24 García Avilés 2010: 18.

25 Existe una tradición en la cual se cuenta que la Virgen posó en vida para que san Lucas pintara su imagen, por lo que a esos retratos y a las esculturas realizadas por san Nicodemo se le atribuyeron propiedades sagradas y todo aquel que no siguiese el modelo, se lo consideraba una distorsión del original. En nuestra leyenda basta con el testimonio del rey Fernando para certificar su autenticidad.

26 García Avilés 2009: 34. 
Será en el siglo XIII cuando el culto y devoción hacia la Virgen alcanzará "un desarrollo inusitado", lo que se verá reflejado en las grandes y variadas colecciones de milagros como la de Gonzalo de Berceo con Los Milagros de Nuestra Señora (1246-1252), Les Miracles de Nostre Dame (c. 1218) de Gautier de Coinci o De Miraculis Beatae Virginis Mariae (c.1143) de Guillaume de Malmesbury, entre otros. ${ }^{27}$ En la tradición cristiana existen numerosos ejemplos de interacción en los que las imágenes santas, al adquirir vida, no solo se legitimaban en su papel de mediadoras con lo sagrado, sino que llegaban a adoptar cualidades rituales y taumatúrgicas. Como bien explica Alejandro García Avilés, ${ }^{28}$ en el manuscrito de Besançon de los Miracles de Notre Dame o las Cantigas (ambos del siglo XIII) entre otros, no es infrecuente que en la imagen de María se encarne la misma Virgen para responder a las súplicas de un enfermo o un orante. Aun así, en tales casos, el acercamiento de la estatua, aunque explícito, suele ser bastante sutil. Además, precisamente va a ser durante ese siglo cuando se difunda la teoría de que las imágenes marianas poseen una virtud sagrada que proviene de su propio prototipo, de manera que

\begin{abstract}
... la creencia en que el objeto material puede cobrar vida y moverse, llorar, sangrar y expresar emociones va cobrando fuerza. Ello se plasmará en términos figurativos con distintos matices. En unas ocasiones las esculturas adoptan diferentes posturas o insinúan movimientos que apuntan a su intervención directa; en otras se trata de visiones, ya que se aparece el prototipo sagrado en el sueño, e incluso en la vigilia. ${ }^{29}$
\end{abstract}

Sin embargo, al referirnos a intercesiones directas realizadas por la Virgen - que en muchas ocasiones redundan en su tradicional papel como madre protectora- es todavía posible aventurarse a retroceder a un mayor tiempo atrás. Hay constancia de una colección de milagros, según recogen los investigadores Alice-Mary Talbot y Scott Fitzgerald Johnson, ${ }^{30}$ que se conservan en el Vaticano en un manuscrito del siglo XII: dicha colección se encuadra en el santuario de Pege, el cual estaba dedicado a la Virgen y fue construido en Constantinopla en el siglo V. De él se dice que allí brotaba un manantial de aguas milagrosas que llegaron a hacer sanar desde campesinos hasta emperadores. Estos milagros raramente fueron mencionados en las fuentes medievales, hasta que a principios del siglo XIV, un historiador eclesiástico puso su interés en ellos y los reescribió con un estilo más elevado añadiéndoles más detalles y hasta quince milagros contemporáneos a su tiempo. En uno de ellos se cuenta cómo un monje, tras despertar de su reposo, "le pareció ver de pie en las que eran llamadas puertas reales a una mujer vestida de púrpura, como una torre tan alta como el lintel en la majestad de su estatura». ${ }^{31}$ Esta le avisó de que el Señor propiciaría en breves instantes un terremoto, para que avisase a la congregación del peligro. A pesar de que lograron salvarse, en la reconstrucción del templo estuvo a punto de ocurrir una desgracia cuando uno de los pintores

\footnotetext{
27 Yarza Luaces 2002-2003: 206-207.

28 García Avilés, 2007.

29 Ibídem.

30 Talbot y Johnson 2012

31 Traducción mía a partir de la reproducción que hacen dichos investigadores.
}

estuvo a punto de caer de un andamio. De nuevo, la «purísima Theotokos» ${ }^{32}$ apareció sobre el ambón sosteniendo la carga de las escaleras para no dejarlas caer.

Volviendo a la Virgen de los Reyes, su intervención para ayudar al santo rey no fue la única vez en la que ha convivido en el plano terrenal: he podido recabar, de una informante sevillana, ${ }^{33}$ una pequeña leyenda con reminiscencias que empiezan a volverse una constante. Cuenta que popularmente es sabido, por aquellos que se encargan de vestir a la imagen, que la Virgen de los Reyes ha sido encontrada más de una vez con el manto sucio por la parte de abajo y con los zapatos desgastados. También hubo un testimonio, en tiempos de la Guerra Civil, que vio a la Virgen paseando por las naves de la Santa Iglesia. ${ }^{34}$

De manera más extensa, reproduce cómo fue el encuentro con el deán de la catedral:

Cuenta la leyenda urbana, que las noches de lluvia y truenos junto a la Catedral, algo raro pasaba. Cuentan que muy caída la noche, aparecía una mujer vestida con una larga capa, vestida de época, que corría despavorida y que no sabían quién era ni de dónde salía. Cuando se acercaban, corría y se perdía por la Catedral hispalense. Una vez, el deán de la Catedral llegó muy tarde, a causa de unos cultos en una de las muchas hermandades de Sevilla. Esa noche llovía y antes de llegar allí, vio a dicha mujer, que al verlo corrió y entró en el Patio de los naranjos del templo.

El deán al verla, corrió tras ella y la persiguió por las dependencias de la Catedral a media luz. A la mujer la perdió de vista de momento, aunque volvió a verla a lo lejos; el pobre hombre la vio entrar en la capilla donde se encuentra la Virgen de los Reyes. Cuando la vio entrar, pensó que ya la tenía capturada, corrió hacia allá y sintió un ruido, cuando llegó, las huellas de la mujer, llenas de barro, llegaba a la misma peana donde se encontraba Nuestra Señora, que estaba desplazada de su sitio [sic].

De nuevo el manto, mojado, sus ropajes movidos, y el cetro caído en el suelo, daban indicios de que milagrosamente había sido la propia imagen la que había descendido de la peana. ${ }^{35}$

Como previamente apuntaba, la actuación de la Virgen en los casos anteriores, dista de una buena mayoría de los milagros mariológicos en los que la revelación de la presencia divina se hace a través de una visión estática - tal y como se suele representar pictográficamente a la imagen, en un rompimiento de gloria que contraste con el resto de la escena del cuadro-. De manera similar, las apariciones acostumbran a producirse tras misteriosos resplandores o con inesperados hallazgos de esculturas en lugares estratégicos, bien en pozos, en campos de labranza - tras haber sido enterradas para preservarlas ante el avance musulmán- o bien escondidas en la corteza de un árbol, pero cuya única acción es la de aparecer una y otra vez en el lugar donde fue encontrada, como una manifestación desiderativa de la ubicación de un santuario para su culto.

\footnotetext{
${ }^{32}$ Del griego Өвото́ко५, significa 'Madre de Dios', (literalmente «la que dio a luz a Dios»).

33 Nombre de la informante: Carmen Ruiz Rodríguez. Edad: 54 años. Procedencia: Sevilla.

${ }_{34}$ Ruiz Rodríguez 2011a.

35 Ruiz Rodríguez 2008.
} 
Aquí, la presencia corpórea de María le permite moverse entre los mortales, pero, para que su identidad no sea advertida, va siempre oculta bajo un manto oscuro o morado. El motivo de la figura embozada se repite en varias ocasiones, como ocurre en varios milagros de Pege y en las versiones de la Virgen de los Reyes. En este último caso, al recurso literario es posible que se le haya unido la tradición, pues se cuenta que el rey san Fernando, cuando aún no había conquistado Sevilla, supo de la existencia que desde «tiempo inmemorial guardaban los moros en su mezquita otra efigie de María que quitaron a los cristianos y que no se atrevían a destrozar, porque los que lo intentaron habían quedado o ciegos o sordos, o con alguna otra lesión». ${ }^{36}$

Se trataba de la Virgen de la Antigua, ${ }^{37}$ cuya leyenda, el jesuita Juan de Villafañe, ${ }^{38}$ en su compendio histórico sobre Vírgenes milagrosas, decía que, para lograr la liberación de la ciudad:

Una vez, pues, que el Santo Rey oraba con mas fervor por este fin ante la Imagen de los reyes, le habló esta Señora, y con voz perceptible le dixo: «En mi imagen del Antigua, de quien tanto fie tu devocion, tienes continua Intercesora: prosigue, que tu vencerás». ${ }^{39}$

Así, tras esta revelación y guiado por un ángel, el rey entró en Sevilla sin que nadie lo descubriera la noche antes de la rendición musulmana, para venerar a la Virgen de la Antigua que, por su intercesión, habría conseguido tomar la ciudad. Según Villafañe, la Virgen había sido emparedada en algún momento de la dominación árabe y esa pared se derrumbó al mismo tiempo que la Virgen de los Reyes le revelaba a Fernando III el poder de la imagen de la Antigua. ${ }^{40}$

La hazaña de cruzar las murallas con tal sigilo tampoco es nueva, puesto que, al igual que la Virgen de los Reyes logró hacer dormir a quienes custodiaban la puerta, en otras hagiografías medievales como la de los Miráculos romanzados de Santo Domingo de Silos, escritos por Pero Marín en el siglo XIII, «describen la aparición nocturna de este santo a los cautivos, su invisibilidad ante los enemigos o la facilidad para penetrar en edificios sin ser percibido por nadie $» .^{41}$

Vemos por tanto, en la leyenda que ha originado este trabajo, que a consecuencia de la intervención activa de la Virgen María, quedan rastros, pistas de su paso cristalizadas en elementos simbólicos que actúan como nexo con lo supraterrernal. Podemos nombrar entre ellos, las llaves de la fortaleza que proporciona al rey mientras duerme, pues le servirán para entrar y conquistar la ciudad. Esas llaves existen y se encuentran expuestas en el museo catedralicio hispalense (Fig. 2). Con respecto a este episodio, cuentan

\section{Puyol 1924: 202-203.}

37 Esto, a su vez, podría venir a explicar el anacronismo que se describe en la leyenda de la presencia de la Virgen en el templo almohade antes de que hubiesen entrado los cristianos.

38 Medianero Hernández se hace eco de otras fuentes que reproducen la misma leyenda, como la del cronista Ortiz de Zúñiga. Asimismo, para mayor información sobre el análisis iconográfico de la Virgen de la Antigua con otras pinturas de similares características y su difusión en diferentes continentes, véase Nuestra Señora de la Antigua. La Virgen "decana" de Sevilla, Sevilla, Diputación Provincial de Sevilla, 2008.

39 Villafañe 1740: 43 citado por Acosta Luna 2011: 38.

40 Ídem.

41 Laguna Paúl 2013: 129.

\section{FIGURA 2}

Las llaves de la ciudad de Sevilla. Museo Catedralicio. Fotografía de la autora

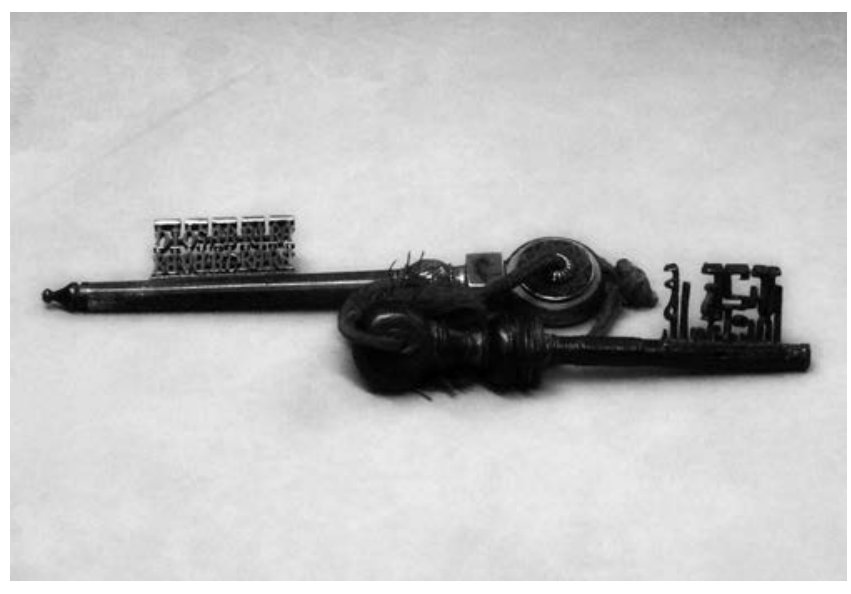

las crónicas que su entrega se produjo el día de la capitulación, el 23 de noviembre de 1248, día de san Clemente, cuando el rey musulmán Axafat se arrodilló ante el castellano en señal de vasallaje y se las dio en mano. De igual manera, la comunidad judía, que también salió a recibirlo, le entregó otra llave. En el vástago de la llave hebrea hay una inscripción calada con caracteres latinos en la que se puede leer «Dios abrirá. Rey entrará», mientras que la compañera lleva una inscripción con caracteres arábigos que significa "Concédanos Allah el beneficio de la conservación de la ciudad $\gg .{ }^{42}$ Esta escena con el rey moro a los pies de Fernando III mientras la Virgen de los Reyes observa el pasaje desde el cielo, tuvo una gran repercusión en la iconografía popular a juzgar por las numerosísimas reproducciones que se realizaron, sobre todo en el siglo XVII, como la que se encuentra en el trascoro de la misma catedral, pintada por Francisco Pacheco en 1634.

Quizás, cuando el tiempo no se hace tan lejano, es posible que la prueba que mayor impacto cause en el oyente o en el lector, sea la constatación, en las propias prendas de la Virgen, de su deambular fuera de su camarín. Dejando a un lado las ropas heráldicas que componen el ajuar de la imagen, quisiera enfatizar el calzado que presenta esta talla, por su singularidad: se trata de un trabajo hispano con una exquisita decoración donde destaca una flor de lis de color rojo rodeada por estrellas de ocho puntas. La palabra AMOR ocupa el puente del zapato y otras dos estrellas flanquean una cruz con cuatro aves del paraíso. Se ha querido ver un origen mudéjar de esta obra, además de la interpretación de las flores de lis como una referencia a su procedencia francesa, como vienen haciendo los historiadores desde el siglo XVI. Esa flor, además, posee su propia simbología mariana, aludiendo a la Trinidad, mientras que las estrellas o flores con ese número de pétalos, se asocian en la iconografía cristiana a la Estrella de la Mañana y a la Madre de Dios. ${ }^{43}$ Sin duda, un calzado muy apropiado para proteger a los celestiales pies de mezclarse con el polvo.

Pero, además del peso de una antigua tradición, ¿qué impulsaría entonces, a que, precisamente esa imagen,

\footnotetext{
42 Laguna Paúl 2002: 266.
}

43 Laguna Paúl 2013: 140. 
de entre toda la pléyade de tallas que se cobijan bajo las capillas de la ciudad sevillana, sea la que mantenga esa historia en la que la divinidad se encarna en la materia inerte para pasear como una misteriosa sombra fuera de su templo?

La respuesta, como en toda leyenda, remite a la propia realidad. La escultura de la Virgen de los Reyes, como bien documenta José Hernández Díaz en su citado estudio, resulta ser un maniquí de tamaño natural articulado, el cual, si lo cambiamos de su habitual postura sedente y es colocado de pie, mide un metro y setenta y seis centímetros. Con una delicada piel de pergamino que le cubre el cuerpo, posee además una "abundante madeja de hilos de oro [que] forman una poblada y oblonga cabellera», ${ }^{44}$ en buen estado a pesar del desgaste de los hilos. No obstante, además de ser la mejor escultura conservada del siglo XIII, lo más reseñable es la existencia de una portezuela en su espalda que cierra el hueco donde se instala un dispositivo especial consistente en

... una rueda dentada, con su pletina de rotación y su cuerda de fleje correspondientes al mecanismo medieval de movimiento de la cabeza, inutilizado hace más de un siglo. Este dispositivo permitía la colocación del rostro y responde a la misma tipología que dibujó Villard de Honnecourt en el cuerpo de un águila cuya cabeza giraba cuando el diácono realizaba las lecturas y debió ser bastante habitual en el siglo XIII. ${ }^{45}$

Por si fuera poco, la escultura posee además unos pasadores de madera que le permiten articular los brazos y las piernas, de manera que se puede intercambiar su posición sedente o levantada, así como las manos, talladas en forma de peine, también pueden hacer movimientos de rotación y flexión por lo que son susceptibles de colocarse en la posición deseada, además de la habitual en la que sostiene al Niño sobre el regazo. ${ }^{46}$

Es decir; la imagen verdaderamente se movía y sus miembros eran capaces de adoptar diferentes posiciones más allá del mayestático hieratismo que había caracterizado hasta entonces a las vírgenes románicas.

«Difícilmente podrá encontrarse otra época en la historia cristiana, en la que la figura de la Madre de Cristo se haya otorgado mayor grandeza representativa. Todo respira ambiente mariano, y hasta los artistas, lograron captar la profundidad teológica de este gran proceso iconográfico», apunta Hernández Díaz. El culto a los iconos comenzó a difundirse por Occidente a partir del 1204, cuando se produjo la conquista de Constantinopla — por lo que no resulta extraño que tuvieran también allí su cuna las leyendas, como hemos visto en el caso de Pege- - Sería allí, en el arte cristiano de Oriente con los primeros tiempos eclesiásticos, donde el tema de la Virgen en Majestad fijó el tipo de iconografía bizantina que más tarde se extendió por Europa. Va a ser el arte románico francés el que se erija como la referencia plástica de este tipo de representación, irrigando su influencia a otros núcleos europeos a través de miniaturas, portadas o vidrieras, pero muy especialmente a través de la

\footnotetext{
44 Hernández Díaz 1996: 25.

45 Laguna Paúl 2013: 138.

46 Para una descripción más detallada, consúltese Arquillo Torres
}

escultura, que durante los siglos XII y XIII vive un momento de grandes avances escultóricos que llegan a su apogeo bajo el reinado de san Luis.

La imaginería mariana recibió ciertos influjos realistas procedentes quizás en gran parte de las tierras germánicas y por ello encontraremos que la representación de la Reina dará origen a figuras que sólo tienen modeladas cabezas, manos y pies, con el fin de revestir sus maniquíes articulados con túnica y mantos reales y conseguir la máxima fuerza expresiva de valor empírico.

Como previamente se había esbozado, el hecho de que aparezca una flor de lis en los zapatos de la talla dio lugar a la tradición histórica de que la virgen fue modelada en Francia por encargo de la reina doña Blanca y de su hijo el rey san Luis, como un regalo de este a su primo Fernando III. Pero al parecer, desde el siglo XVII se viene afirmando que la imagen se hizo en Alemania por petición del rey castellano al emperador Federico $1 \mathrm{I},{ }^{47}$ quien se la envió con fastuoso acompañamiento, durante el sitio de Sevilla. Y es debido a la manera de trabajar la madera y al realismo que le aporta la policromía la razón por la que Hernández Díaz se inclina más por la segunda teoría de la procedencia germánica de la imagen. ${ }^{48}$

Siendo así, no erraría tampoco la leyenda en cuanto al origen de los enigmáticos peregrinos.

Por desgracia, debido a los estragos del tiempo y a la escasez de una documentación suficientemente completa, tenemos una idea parcial de cómo sería la escenificación de la liturgia en la Edad Media. En buena medida además, sí que se tiene constancia, ya desde el Antiguo Egipto o la Grecia Clásica, de la voluntad de dotar de movimiento a las esculturas; de animarlas en el sentido de darles "ánima» o alma, que se hace patente por su capacidad dinámica. ${ }^{49}$ Dicha tradición, con una finalidad manifiestamente religiosa, seguiría perviviendo a lo largo de la Edad Media europea, llegando a confeccionarse, bajo los dominios del Islam, las más complejas técnicas, como refiere Cornejo Vega. ${ }^{50}$ Este tipo de escultura proliferará en la Baja Edad Media, tanto en Europa occidental como territorio español, distinguiéndose dos grandes tipologías de imágenes articuladas: los crucificados (siendo uno de los ejemplos más emblemáticos el Cristo de los Gascones de Segovia) y la Virgen con Niño como Thronum Maiestatis. Los primeros, además de sus numerosas articulaciones que daban movilidad a cuello, hombros, manos o rodillas, poseían detalles de gran realismo y eran figuras que podían aparecer escenificando tanto la crucifixión como el descendimiento, en función de las celebraciones de la liturgia pascual en las que se recreaba teatralmente diferentes momentos de la Pasión.

Con respecto a las imágenes marianas, estas eran utilizadas durante las festividades navideñas, en la celebración epifánica del Officium pastorum sobre la anunciación a los pastores o del Ordo Stellae sobre el episodio de la visita de

47 La fuente para esta teoría en la que se basa Hernández Díaz es un manuscrito del licenciado Alonso Sánchez Gordillo Ilamado Religiosas estaciones que frecuenta la devoción sevillana, existente en la Biblioteca Colombina. Folio 168.

48 Hernández Díaz 1996: 14-21.

49 Ciocchini 1988 citado por Cornejo Vega 1996: 240.

50 Ídem. 
los Magos a Belén, ${ }^{51}$ como pone de manifiesto el texto francés de Nevers, datado en el siglo XI..$^{52}$

Más allá de las bases investigadoras que en su día expuso el historiador de arte Émile Mâle en lo tocante al influjo de los dramas litúrgicos sobre las artes plásticas, ${ }^{53}$ se puede establecer una clara conexión entre la escenificación teatral y el acto litúrgico, sobre todo si consideramos que la Misa, por su escenificación, es en su esencia un misterio dramático, de tal forma que resulta innegable que la liturgia medieval alcanzara «un grado de dramatización y gestualización que favoreció la aparición de manifestaciones espectaculares». ${ }^{54}$

En esa línea viene a incidir las investigaciones de la profesora Laguna Paúl en cuanto a la configuración de la disposición espacial con la que fueron transformadas las estancias de la otrora mezquita a mano de los nuevos ocupantes cristianos. En su excelente recreación de las transformaciones de la Capilla Real, va a poner el acento en el aspecto que va a presentar el altar mayor, donde se colocaría a la imagen de la Virgen de los Reyes. Dicho altar fue elegido como espacio funerario para Fernando III y su familia, de forma que las ceremonias religiosas adquirieron, a su vez, una dimensión política. Será Alfonso $X$ quien aliente la veneración de la memoria de su padre, y por ende, el enaltecimiento de su dinastía, a través de un programa ideológico que fue afianzado por reyes posteriores. Una parte muy importante de este programa es la escenografía sacra diseñada (y reeditada a lo largo de los siglos) para acoger las exequias fúnebres de tal forma que ocasionara un fuerte impacto visual en los fieles y súbditos que acudían a la catedral para orar o para tomar parte en la celebración de aniversarios cultuales tales como la conmemoración de la conquista, con procesiones donde se trasladaban elementos simbólicos como la espada y el pendón que pertenecieron al santo rey. Así se nos describe cómo sería la disposición del altar, desde los ojos de un visitante:

Los sepulcros reales y el altar de la Virgen formaban una composición ascendente, con un plano celestial y otro intermedio o regio donde los monarcas en actitud mayestática, sentados bajo un sitial triple, la antigua sedilia litúrgica, velaban las cajas de sus restos mortales y eran la escenografía tridimensional de la imagen del poder en la tierra. La elevación de la capilla mostraba a los soberanos muy cerca de la Reina del cielo y los fieles observaban las ceremonias desde las naves,

51 Ambas piezas tienen su origen en los denominados 'tropos', que son interpolaciones breves en un texto litúrgico, aprovechando una frase musical sin letra en el canto o con una melodía, y que con el tiempo desarrollaron una estructura dialogada y un mayor grado de desarrollo dramático y espectacular. Para conocer en mayor profundidad la relación entre drama y arte, véase González Montañés 2002.

52 En dicho texto, "se recoge un diálogo entre los clérigos disfrazados de Reyes Magos con Herodes y las parteras, y donde éstas contestan a las preguntas de los Magos señalando al Niño, que en este momento movería los ojos y la cabeza» (Freedberg, David. 1992 El poder de las imágenes; Madrid. Cátedra. Citado por Cornejo Vega 1996: 242).

53 Actualmente, se ha rebatido en muchos estudios este determinismo que refleja en sus trabajos sobre L'Art Religieux du XIIle siècle en France (París, 1898) y L'Art religieux de la Fin du Moyen Âge en France (París, 1908) acerca de la influencia que ejerce una manifestación artística sobre la otra, por lo que las concomitancias entre arte y teatro se comprenderían por el uso de fuentes literarias comunes.

${ }_{54}$ González Montañés 2002: 66. presididas por la Virgen, resplandeciente en el interior de unos tabernáculos extraordinarios, sumariamente representados en los sellos medievales, cuyos batientes abiertos realzaban su presencia en los momentos de culto u ocultarla para destacar la atención en el espacio funerario. Cuando el tabernáculo estuviera cerrado y la Virgen oculta en la penumbra de la capilla los reyes con sus sepulcros serían, prácticamente, los únicos elementos visibles, los protagonistas de un espacio parateatral donde la corte regia es como es, porque Dios de este modo lo ha ordenado. ${ }^{55}$

Queda así puesta de manifiesto la importancia tanto del ámbito cultual que enmarcaba a la imagen como de la propia talla en sí, para desarrollar una liturgia entroncada con lo teatral en la que solo queda imaginar - a falta de alguna fuente que lo refrende- cómo sería la participación de la Virgen de los Reyes. Una participación de la que se desprende, por el efecto creado en los fieles, que pudiera ser la simiente de la que brotaron sus leyendas.

\section{LAS SOMBRAS DE ULTRAMAR}

Como consecuencia de los procesos de evangelización que iban extendiéndose por Nuevo Mundo, las sombras que aparecían (o desaparecían) en extrañas circunstancias, comenzaron también a manifestarse al otro lado del océano. Hay constancias ya desde el año 1510 de la devoción que despertaba la Virgen de la Antigua en ambas orillas del Atlántico. Mientras que en la Península se la reconocía como un símbolo de la victoria contra el islam, la misma situación será recreada durante los primeros años de la conquista de América. La introducción de su devoción se verá motivada por quienes practicaban «una religiosidad que se basaba en la creencia en imágenes marianas capaces de conceder favores como la victoria». ${ }^{56}$

Buen ejemplo nos lo ofrece en 1754 el P. Pedro Lozano, en su Historia de la Compañía de Jesús de la Provincia de Paraguay, ${ }^{57}$ en donde una población de españoles que habitaban la antigua provincia de Tucumán, poseía una imagen de la Inmaculada Concepción, famosa por sus muchos milagros. Por aquel entonces, numerosas tribus de indios se habían levantado en son de guerra y superaban en gran número a los soldados que quedaban, además de mujeres y ancianos, quienes, al verse desamparados, fueron a implorar a la Virgen.

Pero cuál fue su sorpresa, cuando, al entrar en la iglesia y dirigir los ojos al camarín de la Limpia Concepción, repararon que la sagrada efigie había desparecido. [...] Al fin, después de varios días, reaparece la imagen, pero toda cubierta de polvo y con el manto desgarrado con espinas y abrojos, que bien examinados, se reconocieron no ser propios de aquel valle, sino de lo que sólo se criaban en el valle de Calchaqui. ¿Dónde había estado entretanto la Virgen?

A pesar de encerrarla bajo llave, el episodio siguió repitiéndose varias noches más sin que el anciano que estaba a su cargo pudiese evitarlo. Mientras tanto, «los soldados españoles, fatigados de tantas luchas, y reconociendo que

\footnotetext{
55 Laguna Paúl 2013: 154.

56 Acosta Luna 2011: 41.

57 citado por Severino de Santa Teresa 1954: 329-332
} 
les sería imposible acabar de rendir a tantos millares de indios", enviaron un mensajero en busca de ayuda. Los calchaquíes, adivinando el movimiento, se apresuraron a atacar a la indefensa población del Valle Viejo. Sin embargo,

... al estar ya cerca del pueblo, ven al aire a la Majestad de la gran Reina Nuestra Señora del Valle, que, saliéndoles al encuentro y puesta sobre los barrancos de la ribera del río, despedía rayos de su presencia y arrojaba lanzas y saetas de fuego sobre aquella feroz horda de asesinos; y al mismo tiempo, formándose un horroroso huracán y envolviéndolos en nubes de tierra, les pone en acelerada fuga.

Será fundamentalmente en la segunda mitad del XVI cuando se empieza a tener noticia de la existencia de imágenes milagrosas procedentes de España. Debido a la hegemonía que adquirieron los puertos de Sevilla y Cádiz gracias a la creación de la Casa de Contratación, estos representaron durante los siglos XVI al XVIII la puerta de entrada al Nuevo Mundo y como fruto del tráfico económico entre España y las colonias de ultramar, allí llegaron estampas y libros, lienzos y esculturas que empezaron a gozar de un creciente carácter devocional. De la misma manera, numerosos artistas italianos y españoles desembarcaron en las Indias y «serían ellos los encargados de transmitir sus conocimientos, adquiridos en Europa, a sus contemporáneos en América». ${ }^{58}$

Aunque desde los estudios de historiografía del arte colonial se ha querido ver en varias imágenes ejemplos de influencia indígena, es indudable que las imágenes «evocan ante todo diversos modelos del arte europeo». Las vírgenes adquirirán la característica fisonomía "de triángulo», debido al vestuario postizo con el que se revestían - una práctica que venimos encontrando desde Bizancio-. Algunos especialistas señalan a la Virgen de los Reyes como la primera, o una de las primeras en ser imagen de vestir en España, como ya se relataba en la citada cantiga número 295 . Las imágenes americanas continuarán con esta tradición, por tanto, difícilmente se puede hablar de que se produjera un sincretismo entre el culto indígena y el cristiano. ${ }^{59}$

Es evidente que, al mismo tiempo que llegaban nuevas imágenes, estas traían consigo sus respectivas leyendas, las cuales comenzaron a proliferar como instrumento de evangelización. Encontraremos pues, claros paralelismos en la forma en la que se manifiesta la divinidad, la cual se muestra compasiva y protectora con todos aquellos moradores autóctonos que siguiesen su credo.

Cerca de los márgenes del río Luján, en la provincia de Buenos Aires, se tiene noticia de otro suceso sobrenatural. La portentosa imagen de Luján había escogido para guardar su culto a un esclavo: un niño africano llamado Manuel.

La inocente simplicidad del negrito era tal, que algunas veces trataba a la Virgen con extremada familiaridad. Fue el caso que, habiéndosele hecho una

58 Un caso al que se hace referencia es el de Bartolomé Murillo, quien siendo muy joven, expresó su voluntad de embarcarse a tierras americanas. No se tiene constancia de que finalmente realizara este viaje, pero sí de que su hijo arribara al Reino de Nueva Granada en la década de 1670. Asimismo, es sabido que artífices de grandes obras como Francisco de Zurbarán, José y Alejo Fernández o Martínez Montañés exportaron su trabajo a las nuevas tierras conquistadas, Acosta Luna 2011: 143.

59 Ibídem: 139-160. capilla a la Virgen y estando ya colocada la imagen en el nicho, reparó Manuel que algunas noches faltaba del nicho, y por la mañana ya la encontraba en él, pero con el manto y la saya lleno de abrojos y cardillos y por las fimbrias polvo y algún barro; y en estas ocasiones, él decía: «Señora mía, ¿qué necesidad tenéis vos de salir de casa para remediar cualquier necesidad, siendo como sois tan poderosa? ¿Y cómo vos sois tan amiga de los pecadores que salís en busca de ellos cuando veis que os tratan tan mal?». ${ }^{60}$

Una vez más, la Virgen acude nocturnamente a socorrer a sus fieles y a todo aquel que fuera merecedor de su amparo. Cuando tal hecho llega a ser sabido por las autoridades, el lugar en el que se encontraba pasó a ser un enclave de peregrinación, hasta que finalmente se le pasó a construir un santuario que pudiera acoger a todos los feligreses.

No es la única imagen que tiene fama de abandonar su acostumbrado altar para adentrarse en calles aledañas durante sus paseos nocturnos, embozada en un manto y una saya, como una criolla. Existe en la capital ecuatoriana una imagen de la Inmaculada Concepción que tiene la particularidad de ser una virgen alada. ${ }^{61}$ Se trata de una escultura de bulto redondo, de 30 centímetros de alto, tallada con gran cantidad de detalles y con una magnífica sensación de movimiento (tanto que también es apodada como la Virgen bailarina). Bajo sus pies, se encuentra un dragón, al que somete con una cadena de plata que sostiene entre sus manos. Hay quien dice que esas cadenas son precisamente para que la quiteña imagen de la Virgen de Legarda, con su etérea fisonomía, no logre escaparse.

A veces, las ausencias reiteradas de la Virgen no son con fines tan pacíficos, como ocurre con la Virgen de la Natividad, cuya leyenda nos transporta a inicios del siglo XIX:

Cuentan que una mujer de negro andaba regando municiones a los tabacundeños que se habían ido a una guerra... y que una viejita vestida de negro se cruzaba por entre la tropa; que recibía el impacto de numerosas balas y que no caía. Regresan de la guerra los tabacundeños y van a orar al templo y ven asombrados agujereado y con olor a pólvora el manto de la Virgen de Natividad. ${ }^{62}$

A modo de broche, recogemos aquí otra leyenda sin salir de la misma región andina, sobre la Virgen del Quinche. Tiene lugar en los años de 1580, cuando una peligrosa plaga de osos atacó al antiguo pueblo de Oyacachi, contándose entre las pérdidas numerosas vidas de niños.

En estos días, extraña y casualmente pasaba por ahí una mujer con una criatura en brazos que los consoló y les ofreció librarle de la plaga de osos. Los indígenas estaban dispuestos a cualquier cosa por conseguir vivir nuevamente en paz, así que le preguntaron qué debían hacer. La extraña mujer les dijo que la única condición para que ella les ayudase era que pidieran al sacerdote de la población más cercana que les instruyera en el evangelio y los convierta a la religión católica.

60 Cepeda 1925: 82-90.

61 Esta peculiar iconografía que obtuvo gran aceptación en la época, se le atribuye a Bernardo de Legarda (c.1700-1773) convirtiéndose esta talla en la mayor representante de las piezas producidas por la escuela quiteña, la cual llegó a alcanzar gran prestigio mundial.

62 Puga 1998: 11, citado por Mármol 2001. 
Los indígenas en un primer momento se mostraron reticentes, por lo que la aparición de la mujer desconocida volvió a ocurrir hasta dos veces más con la misma petición. Esta mujer solía aparecer a la caída del sol y, aunque los aborígenes la invitaban a pernoctar en la villa, la mujer seguía recorriendo el camino, peligroso e intransitable cuando no había luz.

Como, a pesar de ello nunca mostraba ningún rasguño, ante tal muestra de espectacularidad, los oyacachenses probaron suerte y se hicieron evangelizar, construyendo una rústica capilla. Los osos desaparecieron, por los que «le concedieron el milagro a la desconcertante mujer. Ahora solo faltaba una imagen católica a la que venerar». Cuando, corriendo el año 1590, el escultor don Diego Robles se entera del hecho, acude al pueblo con una talla. "Al verla los indígenas oyacachenses se quedaron estupefactos porque, según decían, era la misma señora que se les apareció en la cueva por tres ocasiones; por esta razón no dudaron en adquirirla».

No tardó la imagen en conceder milagros y abandonar durante las noches la humilde grieta de su roca para ir a curar a los enfermos. Tal fue el fervor que despertó, que con el tiempo decidieron trasladarla a un lugar más accesible para que acudiera la congregación, por lo que se le construyó un templo en la población más cercana: el Quinche, de ahí su advocación. ${ }^{63}$

\section{CONCLUSIONES}

La profundidad radicular que alcanzan los relatos populares, nos retrotrae a tradiciones que surcan siglos y continentes en los que, allá donde una voz vuelve a contar la misma historia, deja de nuevo la huella de asombro en quien la escucha. Las leyendas, en pos de superar la controversia medieval sobre la veneración a los iconos, han servido para asentar la legitimidad de la imagen material, la cual, al tener el poder de manifestarse, adquiere un hálito de espiritualidad que le permite convertirse en mediadora entre Dios y los seres humanos. Pero su mediación no se limita al socorro de quien ora en busca de amparo, sino que el radio de su acción se extiende a la protección de un lugar, a la conversión a la religión cristiana, a castigar a los herejes, a asegurar triunfos militares o a prodigiosas sanaciones.

Todo ello en su conjunto ha dado lugar a fecundas manifestaciones artísticas reflejadas en todos los campos. La Virgen de los Reyes es un exponente de la evolución de convenciones iconográficas de tradición bizantina en la que «parece haber una correlación directa entre lo arcaico y la inmanencia de la divinidad». Posteriormente, durante la Edad Media, ese hieratismo ganará en características emotivas y expresivas propias de los humanos. ${ }^{64}$ Pero la solemnidad que encierra su apariencia y engalanamiento regio, no resta familiaridad a su sonrisa como madre afectuosa, ${ }^{65}$ sino más bien, ese intento de animación, así como la viveza de la

63 Salazar Median 2001: 29-51.

64 Freedberg 1992: 54, 344.

65 La figura maternal de la Virgen con el niño se traduce en el epítome de gracia gótica, muy reproducida por los talleres de París como centro de irradiación y cuyo modelo irá siendo adaptado en diferentes lugares. Rubin 2010: 123. pintura en color, permite un efecto realístico y psicológico que es percibido por los fieles como una mayor eficacia y autenticidad de la imagen.

Tal aspecto material, en conjunción con la literatura hagiográfica y la historiografía, potenciaron el culto de estas imágenes como una forma de legitimación política e incentivo de la devoción y al mismo tiempo como herramienta edificadora o fuente doctrinal para la población analfabeta.

En las historias orales que circulaban sobre imágenes marianas cuyos miembros lignificados cobran vida, encontraremos patrones de actuación que llegan a convertirse en tópicos narrativos y cuya clave reside en las pruebas de esas acciones para dar veracidad al poder de lo sagrado.

Esos motivos - que solo gracias a la divinidad se pueden volver a recrear-, ya fueron usados en distintas sociedades, en reiteradas reactualizaciones "al ser transcritos por laicos o religiosos que los reinterpretaron según los dogmas establecidos" y que fueron ampliamente difundidos gracias a la imprenta durante los siglos XVI y XVII. ${ }^{66}$ Esa popularización promovió la producción cultural de ilustres artistas de la época y de igual manera, esos tópicos se exportarán y arraigarán en remotos lugares de América e incluso Asia, ${ }^{67}$ siempre conservando el origen y la actuación ontológicamente sobrenatural de estas imágenes.

Asegura Freedberg que "cuanto más intensa es la experiencia de las cualidades estéticas de la imagen, mayores parecen ser los poderes que trascienden de la naturaleza inanimada", ${ }^{68}$ tal y como se reflejan en muchas leyendas. Por todo ello es innegable el valor historiográfico y etnográfico de estos relatos para comprender el poder evocador de las imágenes y el vínculo que lo sagrado despierta en el sentido de identidad colectiva. En palabras de Peter Brown, el icono se convirtió en la «expresión visible de un nexo invisible ${ }^{69}$ entre la imagen representada y la comunidad donde tiene lugar el milagro.

Desde la distancia de nuestros días, quizás se haya desvanecido la importancia del eco repetitivo de la voz humana como vehículo que nos conduce hacia el hallazgo de nuestra propia autenticidad. Pero sobre todo, el valor de la oralidad ha residido en su establecimiento como vínculo con esa otra vida posible, transmitida en las leyendas en la que lo maravilloso se hace tangible para el creyente y la fe en las palabras lo hace partícipe del misterio divino.

\section{BibLIOGRAFÍA}

Acosta Luna, O. I. 2011. Milagrosas imágenes marianas en el Nuevo Reino de Granada. Madrid-Franckfurt: Iberoamericana-Vervuert.

Alfonso X, Rey de Castilla 2009. Cantigas de Santa María. Alicante: Biblioteca Virtual Miguel de Cervantes; Madrid: Biblioteca Nacional. Disponible en <http://www.cervantesvirtual.com/obra/ cantigas-de-santa-maria> Fecha de acceso: 12 mayo 2017.

Arellano, I. 2000. "Algunos aspectos del marco historial en los autos sacramentales de Calderón», en J. Alcalá-Zamora y A. Pérez Sánchez (coords.), Velázquez y Calderón: dos genios de Europa (IV centenario, 1599-1600, 1999-2000): 221-248. Madrid: Real Academia de la Historia.

66 Navarro 2013: 351.

67 Véase Medianero Hernández, J.M. “Copias de la Virgen de la Antigua en Japón”, Laboratorio de Arte, n. 9, 1996, pp. 323-332.

68 Freedberg 1992: 342-343.

69 Brown 1989 citado por Belting 2009: 86. 
Arquillo Torres, J. 1989. Aspectos socio-religiosos en la conservación de las presentaciones escultóricas marianas. Influencia en tres imágenes medievales representativas. Tesis doctoral dirigida por F. Arquillo Torres. Sevilla: Universidad de Sevilla.

Belting, H. 2009. Imagen y culto. Una historia de la imagen anterior a la edad del arte. Madrid: Akal.

Carrero Rodríguez, J. 1989. Nuestra Señora de los Reyes y su historia. Sevilla: J. Rodríguez Castillejo Editor.

Cepeda, F. A. 1925. América mariana o sea Historia compendiada de las imágenes de la Santísima Virgen más veneradas en el Nuevo Mundo. Madrid: Editorial del Corazón de María.

Cornejo Vega, F. 1996. "La escultura animada en el arte español. Evolución y funciones». Laboratorio de Arte (9): 239-261.

Freedberg, D. 1992. El poder de las imágenes. Estudios sobre la historia de la teoría de la respuesta. Madrid: Cátedra.

García Avilés, A. 2007. «Imágenes 'vivientes': idolatría y herejía en las Cantigas de Alfonso X el Sabio». Goya. Revista de Arte 321 (noviembre-diciembre): 324-342. Disponible en: <http://www. cervantesvirtual.com/obra-visor/imgenes-vivientes-idolatra-yhereja-en-las-cantigas-de-alfonso-x-el-sabio-0/html/0235cf5682b2-11df-acc7-002185ce6064_11.html> Fecha de acceso: 22 dic. 2016.

García Avilés, A. 2009. «Transitus: actitudes hacia la sacralidad de las imágenes en el Occidente medieval», en Imágenes medievales de culto tallas de la colección El Conventet: 24-35. Murcia: Dirección General de Bellas Artes y Bienes Culturales.

García Avilés, A. 2010. "Imagen y Ritual: Alfonso X y la creación de imágenes en la Edad Media». Anales de Historia del Arte no extra 1: 11-29.

González Montañés, J. I. 2002. Drama e iconografía en el arte medieval peninsular (siglos XI-XV). Tesis doctoral dirigida por V. M. Nieto Alcaide. Madrid: UNED.

Hernández Díaz, J. 1996. Estudio iconográfico de la Virgen de los Reyes. Sevilla: Guadalquivir.

Laguna Paúl, T. 2002. "Las llaves de la ciudad de Sevilla», en I. Bango (coord.): Memoria de Sefarad: 266. Madrid: Central Cultural San Marcos.

Laguna Paúl, T. 2013. «Devociones reales e imagen pública en Sevilla». Anales de Historia del Arte 23 (número especial II): 127-157. https://doi.org/10.5209/rev_anha.2013.v23.42833

Llona, M. (coord.). 2012. Entreverse: teoría y metodología práctica de las fuentes orales. Bilbao: Universidad del País Vasco.

Mármol, J. N. 2001. Mama Nati y su santuario. Folleto disponible en <https://mamanati.files.wordpress.com/2012/10/mama-nati-susantuario.pdf> Fecha de acceso: 07 ene. 2017.

Medianero Hernández, J. M. 2008. Nuestra Señora de la Antigua, la Virgen "decana" de Sevilla. Sevilla: Diputación de Sevilla.
Menéndez Pidal, R. (ed.) 1906. Primera Crónica General, Madrid: Bailly-Bailliere é hijos, editores.

Navarro, A. M. 2013. «Leyendas marianas e imágenes milagrosas en la historia de la religiosidad popular de Andalucía (siglos XII-XVII)». En la España Medieval 36: 327-356.

Puyol, J. 1924. «Jerónimo Münzer. Viaje por España y Portugal en los años 1494 y 1495. (Conclusión)/ versión del latín por Julio Puyol». Boletín de la Real Academia de la Historia 84: 197-279.

Ramos, A. 2008. La ciudad de Dios en Santo Tomás de Aquino. Mar del Plata: Universidad Fasta.

Rodríguez Moya, I. 2007. "Los reyes santos», en V. Mínguez (ed.), Visiones de la monarquía hispánica: 133-170. Castellón de la Plana: Publicacions de la Universitat Jaume I.

Rubin, M. 2010. «Imágenes de la Virgen María». Anales de Historia del Arte $\mathrm{n}$ o extra 1: 109-124.

Ruiz Rodríguez, C. 2008. "Fantasmas y misterios en la catedral de Sevilla». Historia, leyendas y fenómenos de Sevilla (Blog). Disponible en: <http://sevillaciudaddeembrujo.blogspot.com. es/2008/10/fantasmas-en-la-catedral-el-de-coln.html> Fecha de acceso: 22 enero de 2017.

Ruiz Rodríguez, C. 2011. "Curiosidades y leyendas sobre: Virgen de los Reyes, Cristo de la Expiración del Museo, Cristo del Amor y Hermandad de la Carretería» Historia, leyendas y fenómenos de Sevilla (Blog). Disponible en: <http://sevillaciudaddeembrujo. blogspot.com.es/2011/01/curiosidades-y-leyendas-sobre-virgende.html> Fecha de acceso: 22 enero de 2017.

Salazar Median, R. 2001. El Santuario de la Virgen de El Quinche. Peregrinación en un espacio sagrado milenario. Quito: Ediciones ABYA-YALA.

Santa Teresa, S. de 1954. La Inmaculada en la conquista y coloniaje de América. Vitoria: Ediciones del Carmen.

Talbot, A.-M. y Johnson, S. F. (trads.) 2012. Miracle tales from Byzantium. Cambridge, Massachusetts: Harvard University Press.

Yarza Luaces, J. 2002-2003. "Historias milagrosas de la Virgen en el arte del siglo XIII». Estudis d'art medieval 15: 205-246.

Zugasti, M. 2001. "De iconografía mariana en dos comedias del Siglo de oro: La Virgen de los Reyes de Hipólito de Vergara y La aurora en Copacabana de Calderón», en G. Vega García-Luengos e I. Arellano Ayuso (eds.), Calderón: innovación y legado: actas selectas del IX Congreso de la Asociación Internacional de Teatro Español y Novohispano de los Siglos de Oro, en colaboración con el Grupo de Investigación Siglo de Oro de la Universidad de Navarra: 425-450. New York: Peter Lang.

Zugasti, M. 2006. «La elaboración del icono de la Virgen de los Reyes en el auto calderoniano El santo rey don Fernando (segunda parte)», en I. Arellano y E. Cancelliere (eds.), La dramaturgia de Calderón: técnicas y estructuras: 637-666. Madrid: Iberoamericana. 